\title{
Evolution of the Great Tehuelche Paleolake in the Torres del Paine National Park of Chilean Patagonia during the Last Glacial Maximum and Holocene
}

\author{
Marcelo A. Solari ${ }^{1,2}$, Jacobus P. Le Roux ${ }^{1}$, Francisco Hervé ${ }^{1,3}$, Alessandro Airo ${ }^{4}$, Mauricio Calderón ${ }^{5}$ \\ ${ }^{1}$ Departamento de Geología, Facultad de Ciencias Físicas y Matemáticas, Universidad de Chile, Casilla 13518, Correo 21, Santiago, \\ Chile. \\ msolari@cec.uchile.cl; jroux@cec.uchile.cl; fherve@cec.uchile.cl \\ 2 Geohidrología Consultores Ltda., Vitacura 2909, Of. 601, Santiago, Chile. \\ msolari@geohidrologia.cl \\ 3 Escuela de Ciencias de la Tierra, Facultad de Ingeniería, Universidad Andrés Bello, Sazié 2350, Santiago. \\ 4 School of Earth Sciences, Stanford University, 450 Serra Mall, Bldg. 320, Rm. 118 Stanford, CA 94305, USA. \\ aairo@stanford.edu \\ 5 Servicio Nacional de Geología y Minería, Casilla 10465, Santiago, Chile. \\ mcaldera@sernageomin.cl
}

\begin{abstract}
A number of glacial moraines are distributed from the eastern margin of the Torres del Paine drainage basin to near the present margin of the Patagonian Ice Fields, together with a set of regionally continuous lacustrine terraces related to glacial fluctuations. The geomorphology, supported by lake sediment evidence, indicates the existence of a single proglacial paleolake in this area, here referred to as the Great Tehuelche Paleolake. This concept helps to clarify the chronology of glacial events and leads to a better understanding of the evolution of the hydrologic system in the Torres del Paine area. Glacial advances previously referred to as A, B and C occurred during the Last Glacial Maximum and fed the Great Tehuelche Paleolake with meltwater, allowing it to reach its maximum extension. The discovery of thrombolites at Laguna Amarga suggests that the drainage of the paleolake towards the Última Esperanza Fjord took place at 7,113 Cal. yr BP, after the melting of an ice barrier that existed during the earlier glacial advance. This gave rise to the development of a complex fluvio-lacustrine hydrologic system that persists to the present day.
\end{abstract}

Keywords: Patagonia, Last Glacial Maximum, Younger Dryas, Thrombolites.

RESUMEN. Evolución del Gran Paleolago Tehuelche en el Parque Nacional Torres del Paine de la Patagonia chilena durante el Último Máximo Glacial y Holoceno. Un grupo de morrenas glaciales están distribuidas desde el margen este de la cuenca de drenaje de Torres del Paine hacia el margen actual de los Campos de Hielo Patagónicos. Las morrenas se observan en conjunto con un grupo de terrazas lacustres regionales, las cuales están vinculadas a las fluctuaciones glaciales. La geomorfología y evidencias de sedimentos lacustres indican la existencia de un único lago proglacial, referido en este estudio como Gran Paleolago Tehuelche. Este concepto ayuda a clarificar la cronología de los eventos glaciales y permite una mejor comprensión de la evolución del sistema hidrológico del sector de Torres del Paine. Los eventos glaciales, previamente referidos como Avance A, B y C, ocurrieron durante el Último Máximo Glacial y alimentaron con aguas de fusión al Gran Paleolago Tehuelche, permitiéndole alcanzar su mayor extensión. El descubrimiento de trombolitos en Laguna Amarga sugiere que el desagüe del paleolago ocurrió hace 7.113 Cal. años AP por el Seno de Última Esperanza, producto de la fusión de una barrera glaciar existente durante los avances glaciales anteriores. Luego del drenaje se desarrolló en un complejo sistema hidrológico que persiste hasta el presente. 


\section{Introduction}

Milankovitch (1930) was the first to calculate the combined influence of the eccentricity $(100,000$ and 413,000 yr cycles), obliquity (41,000 yrs) and precession of the equinoxes $(23,000 \mathrm{yrs})$ on the amount of solar heat recorded at different latitudes during the last million years. Many decades later, Davis and Bewer (2009) investigated an alternative forcing mechanism based on the role of latitudinal insolation and temperature gradients, to explain the propagation of orbital signatures throughout the climate system, including the monsoon cycle, Arctic oscillation and general ocean circulation.

Studies of stable oxygen isotopes of foraminifers preserved in sediment samples from the Indian Ocean suggest that climatic variations causing the retreat of the ice caps and a rising of sea level are supported by the orbital theory of Milankovitch (Imbrie et al., 1984). In ice cores obtained from Antarctica (EPICA, 2004) and Greenland (North Greenland Ice Core Project, 2004) it is also possible to observe these cycles as predicted by the orbital theory. However, in the ice cores short, irregular and abrupt interglacial stadia that cannot be explained by the orbital theory are also recorded. These short stadia are of almost the same magnitude as those related to glacial or interglacial periods at a 100,000 yr scale, but represent intervals of only hundreds of years (Dansgaard et al., 1993).

Good examples of such abrupt changes include the global warming after the Last Glacial Period and the subsequent glacial advance (Cold Reverse in Fig. 1). Different hypotheses, generally based on inter-hemispheric climate changes, exist to try and explain why these climate variations occurred on earth.

One line of hypotheses based on interhemispheric change postulates that changes in the Milankovitch insolation cycles (Imbrie et al., 1992) or ice rafting events (Bond et al., 1993; Macayeal, 1993; Bond and Lotti, 1995) could have produced variations in the density of the North Atlantic surface water, associated with changing temperature and glacial meltwater fluxes. These could have affected the turnover of the convection, thus linking ocean circulation between the Northern and Southern Hemispheres and modifying the patterns of global heat transfer to high latitudes. The hypothesis is partly supported by an analysis of oxygen isotopes from ice-sheet cores, which suggests that changes in Greenland may have preceded those in the Antarctic (Bender et al., 1994).
A second line of hypotheses based on ice cores from Antarctica (EPICA, 2004), and Greenland (North Greenland Ice Core Project, 2004), suggests that climate variations in the Southern Hemisphere trigger changes in the Northern Hemisphere. Comparison of the ice cores suggests that the warming tendency after the Last Glacial Period started first in Antarctica, from where it spread to Bolivia and then to Greenland (Fig. 1). In addition, the ice cores from Antarctica reveal an abrupt inversion event (the Antarctic Cold Reverse or ACR) before the equivalent Younger Dryas (YD) event of the Northern Hemisphere (Sowers and Bender, 1995; Blunier et al., 1998).

A third line of hypotheses maintains that climate changes occurred simultaneously in both hemispheres. Studies by Denton et al. (1999) in the Lake District of Chile and in New Zealand provided a temporal register of glacial fluctuations that indicates a glacial event simultaneous with the YD event of the North Atlantic region (Lowell et al., 1995; Denton et al., 1999). The good correlation between both sets of observations may indicate that the glacial-interglacial transition between both hemispheres occurred in phase. These conclusions are supported by evidence of events equivalent to the YD in Ecuador (Clapperton et al., 1997) and New Zealand (Denton and Hendy, 1994; Ivy-Ochs et al., 1999). An analysis of glaciers on the Taylor Dome and the Ross Sea Shelf in Antarctica (Steig et al., 1998) supports the hypothesis of simultaneous inter-hemispheric climate changes.

Although the climate variability during the Holocene (after 11,500 yr BP) does not have the same magnitude as the abrupt climate change of the Last Glacial Period, it affected the growth and development of modern civilization. According to Denton and Karlen (1973) glacier fluctuations can be identified at 9,000-8,000, 6,000-5,000, 4,200-3,800, 3,500-2,500, and 1,200-1,000 yrs, and also since 600 yr BP (grey bands in Fig. 1). Mayewsky et al. (2004) examined about 50 globally distributed paleoclimate records that validated the six periods of significant Holocene rapid climate change (HRCC). Most of the climate change events in these globally distributed records are characterized by polar cooling, tropical aridity, and major atmospheric circulation changes, although during the most recent interval (600-150 yr $\mathrm{BP}$ ), polar cooling was accompanied by increased moisture in some parts of the tropics. 
(a)

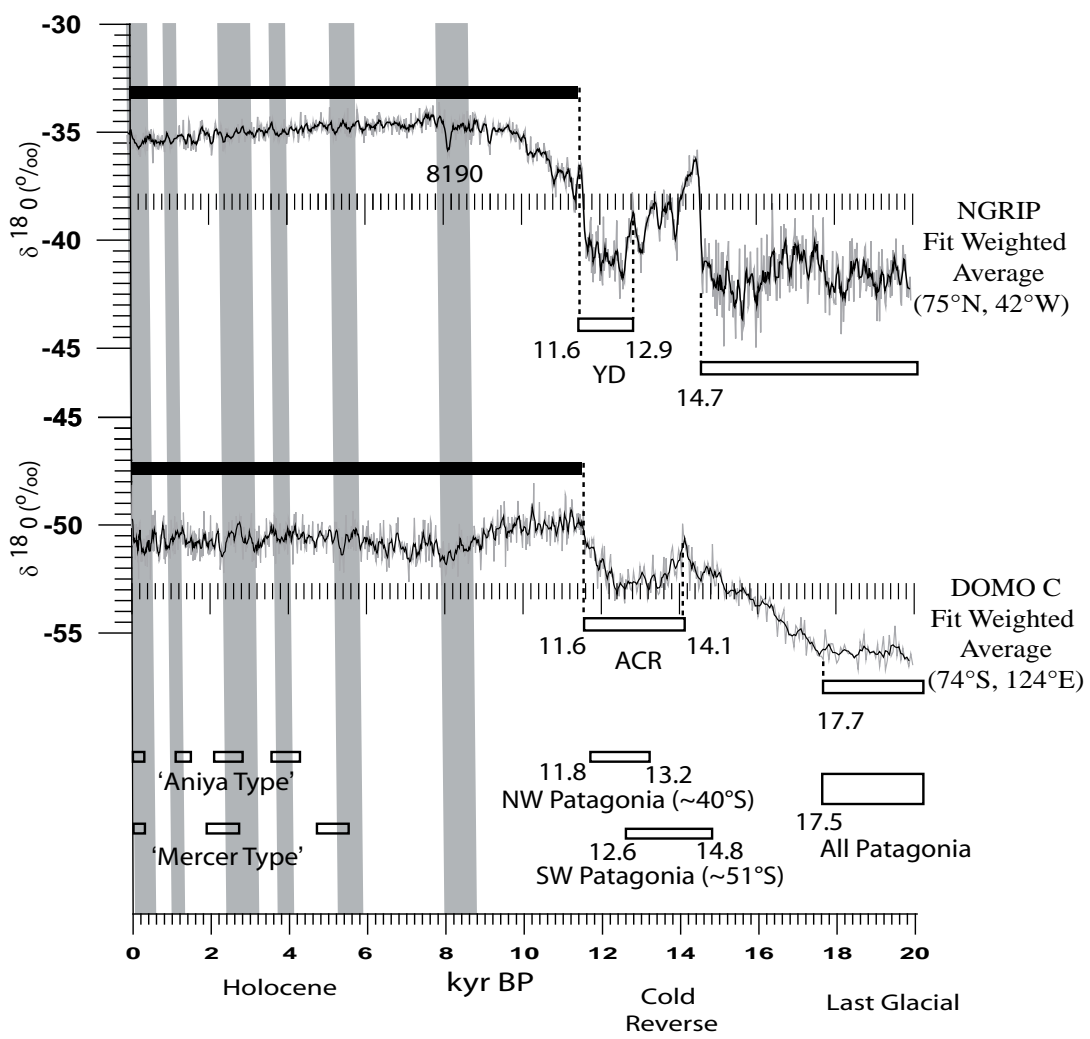

FIG. 1. Ice core $\delta^{18} \mathrm{O}(\mathrm{SMOW})$ paleoclimate and discontinuous glacial advance records. Grey bands represent timing of the Holocene rapid climate change or HRCC (Mayewski et al., 2004) and white rectangles represent cool periods. a. Smoothed weighted average (black line) of NGRIP $\delta^{18} \mathrm{O}$ (grey line) ice core paleoclimate proxy data (NGRIP, 2006; Vinther et al., 2006; Rasmussen et al., 2006; Andersen et al., 2006; Svensson et al., 2006); b. Smoothed weighted average (black line) of Dome C $\delta^{18} \mathrm{O}$ (grey line) ice core paleoclimate proxy data (Stenni et al., 2001, 2003, 2006; Jouzel et al., 2001; Schwander et al., 2001); c. 'Mercer' and 'Aniya' type Neoglacier advances events in Patagonia (Mercer, 1968, 1970, 1982; Aniya, 1995, 1996); Cold Reversal Period in Lake District in northwestern Chilean Patagonia (Hajdas et al., 2003; Moreno et al., 2001), Cold Reversal Period in Torres del Paine (Moreno et al., 2009) and synchronous Patagonian LGM deglaciation.

In this paper we examine climate changes in Chilean Patagonia during the Last Glacial Maximum and Holocene, in order to contribute to the evaluation of the different scenarios outlined above.

\section{Glaciation in Patagonia}

During the Pleistocene, the western part of southernmost South America was buried beneath a thick ice cap, vestiges of which remain in the form of large ice fields in Patagonia (Heusser, 1990, 2003; Heusser et al., 1995). Presently, the Northern Patagonian Ice Field (NPI) lies between about $46^{\circ}$ and $48^{\circ} \mathrm{S}$, whereas the Southern Patagonian Ice Field (SPI) stretches from the southern shores of the Baker Channel almost to Puerto Natales at about $51^{\circ} \mathrm{S}$.
The chronology of Patagonian glaciations is among the most complete in the world and our understanding of the different glaciation periods has made significant progress in the past decade, following the pioneering work of Caldenius (1932), Mercer (1976), Rabassa and Clapperton 1990), Clapperton (1993), Glasser and Jansson (2008) and Glasser et al. (2008). Rabassa et al. (2005) synthesized the existing knowledge of the chronology of the Late Cenozoic Patagonian glaciations: the oldest known glaciations took place between approximately 7 and $5 \mathrm{Ma}$ (latest Miocene-earliest Pliocene; Lagabrielle et al., 2010), while during the middle-late Pliocene, a minimum of 8 glaciations occurred (Oxygen Isotopic Stages 54-82). The Great Patagonian Glaciations (GPG) developed between 1,168 and 1,016 Ma 
(Oxygen Isotopic Stages: 30-34; early Pleistocene), followed by 14-16 cold (glacial/stadial) events with their corresponding warm (interglacial/interstadial) equivalents. Thirteen post-GPG moraines have been identified.

The available evidence indicates that a major glacial advance occurred during Marine Isotope Stage (MIS) 6 with a best age estimate of about 150-140 ka (Singer et al., 2004; Kaplan et al., 2004; Douglass et al., 2006). Kaplan et al. (2005), based on the Antarctic ice core peak in the glacial-age dust concentration at around $75 \mathrm{ka}$, inferred that a major MIS 4 glacial advance or event occurred at Lake Buenos Aires, but was obliterated by the more extensive MIS 2 glacial advances. The LGM occurred between about 30 and 16 ka (during MIS 2), being broadly synchronous across Patagonia (Clapperton and Seltzer, 2001) and with the 'global' ice sheet LGM (Mix et al., 2001). The glacial activity during this period has therefore been the focus of many studies (e.g., Meglioli, 1992; Porter et al., 1992; Denton et al., 1999; McCulloch et al., 2000, 2005; Heusser, 2003; Harrison, 2004; Coronato et al., 2004; Sugden et al., 2005; Wenzens, 2005; Kaplan et al., 2008a, 2008b).

According to McCulloch et al. (2000), deglaciation of the LGM occurred synchronously at $14,600-14,300{ }^{14} \mathrm{C}$ yr BP $(17,500-17,150$ Cal yr BP). Moreno et al. (2009) concluded that the maximum phase of the southwestern Patagonian readvance (about 14.8-12.6 ka) coincided with the Antarctic Cold Reverse in the European Project for Ice Coring in Antarctica (EPICA) Dome C record (Stenni et $a l ., 2003$ ) and that the results differ markedly from those reported for northwestern Patagonia $\left(\sim 40^{\circ} \mathrm{S}\right)$ (Moreno et al., 2001; Hajdas et al., 2003), where moderate cooling between 14.6 and 13.5 ka was followed by an intensification that lasted until about $11.5 \mathrm{ka}$. A warming step occurred at about 10,000 ${ }^{14} \mathrm{C}$ yr BP (11,400 Cal yr BP) throughout Patagonia, achieving Holocene temperature levels.

Glasser et al. (2004) undertook a major revision of the Holocene, mentioning two types of Neoglacial advance, namely the 'Mercer' and 'Aniya' type chronology. Mercer (1968, 1970, 1982) proposed three Neoglacial advances: at 4,700-4,200 ${ }^{14} \mathrm{C}$ yr BP (5,413-4,687 Cal yr BP), at 2,700-2,000 ${ }^{14} \mathrm{C}$ yr BP (2,758-1,893 Cal yr BP) and during the Little Ice Age (LIA) of the last three centuries. Aniya (1995, 1996) later obtained radiocarbon dates from moraines on the eastern side of the Southern Patagonian Ice
Field and recognized four Holocene advances with maxima at 3,600 (3,839 Cal yr BP), 2,300 (2,227 Cal yr BP), 1,600-1,400 (1,455-1,286 Cal yr BP) ${ }^{14} \mathrm{C}$ yr BP and again during the LIA.

The Patagonian Ice Field fluctuation in the southern part of South America has considerable potential to contribute to the debate on interhemispheric climate change. The existence of the Patagonian Ice Field in a temperate, low latitude zone at an average elevation of only about 2,000 m a.s.l., can be explained by the high rainfall resulting from the predominantly westerly winds and frontal systems (Ibarzabal et al., 1996; Carrasco et al., 1998, 2002). Therefore, deciphering the glacial fluctuations of the Patagonian Ice Field and the evolution of the hydrological system around their margins are key factors to understanding the fluctuation of the Westerlies and their relationship with global climatic events.

\section{Study area}

The study area is defined by the Torres del Paine Drainage Basin (TPDB), covering an area of $8,767 \mathrm{~km}^{2}$ and enclosing a complex hydrological system (Solari et al., 2010).

On the western side of the TPDB, meltwater from the Southern Patagonian Ice Field lobes developed a system composed of proglacial lakes feeding various rivers. The Paine River flows into Lago Nordenskjöld, which in turn drains into Lago Pehoe and then into Lago del Toro. The main outlet of Lago del Toro is the Serrano River. The Grey River links up with the Serrano River that flows into the Última Esperanza Fjord (Fig. 2).

The TPDB as a whole had two possible outlets in the past, the first being along the Serrano River into the Última Esperanza Fjord, and the second along the Lago Porteño Valley.

Forming the eastern boundary of the TPDB as well as east of the Baguales and Cazador Ranges are widespread terminal moraines with multiple ridges, providing evidence of older glacial events in the Torres del Paine area.

Marden (1993) mapped the glacial landscape of the Torres del Paine district and determined 8 glacial stages (labelled from west to east: A, B, C, D, E, F, G and H) from the Grey and Tyndall Glaciers to the recent terminal moraines along the coastline of Lago Sarmiento. 


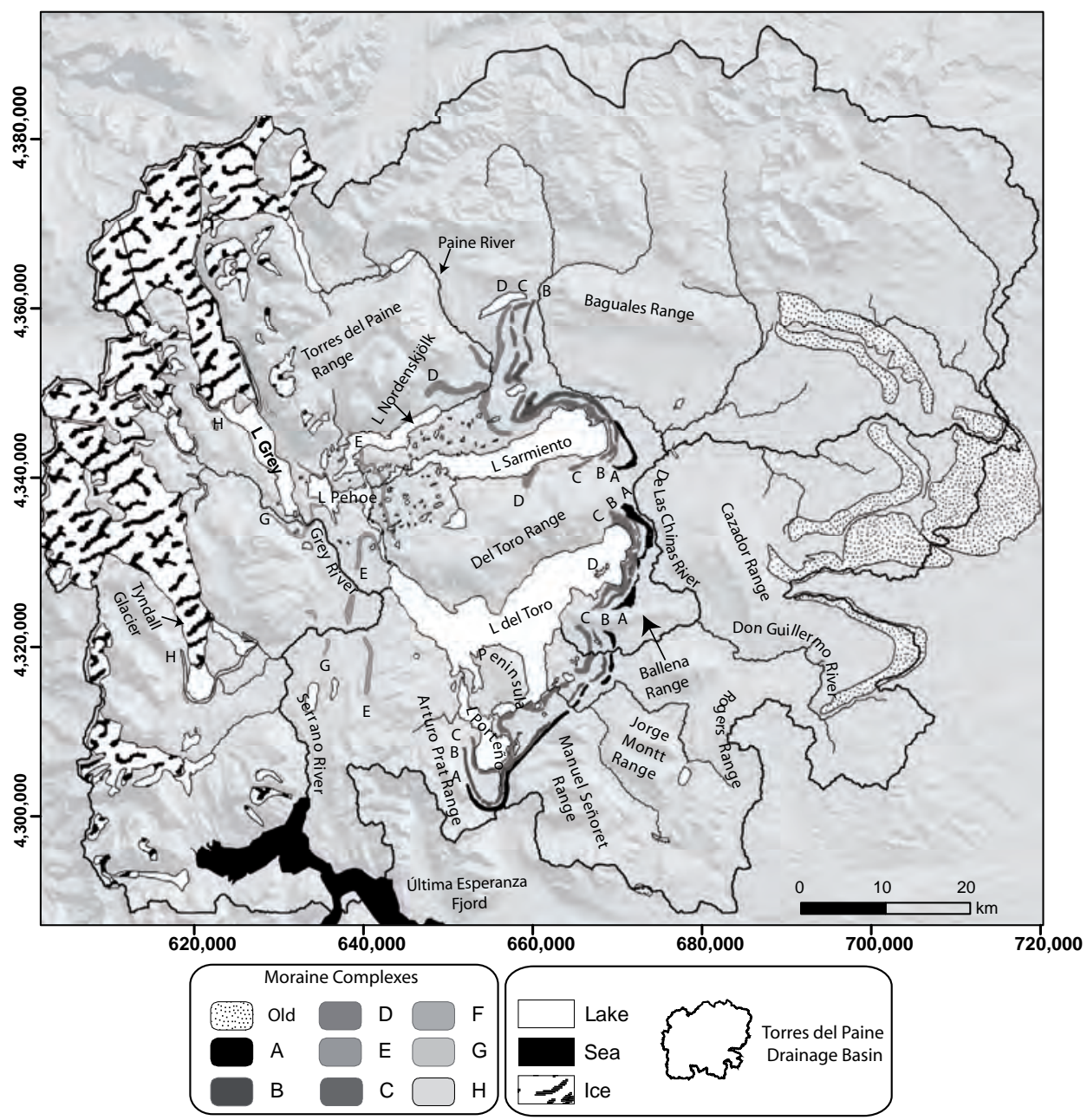

FIG. 2. Torres del Paine Drainage Basin and moraines superimposed on a shaded relief image obtained from the Shuttle Radar Topographic Mapping Mission (SRTM 90 m resolution, UTM 195/ WGS 84) digital elevation model.

Cosmogenic ${ }^{10} \mathrm{Be}$ dating of erratics from the $\mathrm{D}$ moraine indicates a short-lived re-advance of Patagonian ice culminating at 12.6-14.8 kyr BP, coincident with the time of the Antarctic Cold Reverse (Fogwill and Kubik, 2005; Moreno et al., 2009). The radiocarbon age of Glacial Advance $E$ is $9,755 \pm 95{ }^{14} \mathrm{C}$ yr BP, based on dating of the basal part of a peat bog occurring within its limits (Marden and Clapperton, 1995). Two minimum radiocarbon ages for Advance F were obtained: 8,750 $\pm 170{ }^{14} \mathrm{C}$ yr BP from basal organic bog sediments inside the moraine limits (Marden and Clapperton, 1995) and 9,180 $\pm{ }^{14} \mathrm{C}$ yr BP obtained from basal organic sediments close to the inferred advance limits (Stern, 1990). An age control for Advance $\mathrm{G}$ has not been obtained, but it may be correlated with the Patagonian Neoglacial advances (Glasser et al., 2004). The age of Advance $\mathrm{H}$ was determined by studying the annual ring patterns of trees that colonised the moraines in the vicinity of Grey Glacier (Armesto et al., 1992). The age of the oldest tree (Nothofagus pumilio) was estimated at $232 \mathrm{yr}$, and it appears that the most extensive phase of Advance $\mathrm{H}$ at the Grey Glacier culminated at 1,600-1,700 AD, apparently being associated with the Little Ice Age (Marden and Clapperton, 1995).

Following Marden's (1993) study that defines the margins of the different glacial events in the Torres del Paine area, this paper aims to decipher part of the evolution of the hydrological system related to glacial fluctuation. 


\section{Methodology}

During five separate field excursions we mapped the geomorphology and distribution of Quaternary deposits at a scale of 1:10,000, which was supplemented by the analysis of the Shuttle Radar Topography Mission Digital Elevation Model (SRTM DEM ) data (USGS, 2000) and aerial photographs. We also described and measured stratigraphic columns and collected samples for radiocarbon dating. Topographic elevations were determined using a handheld GPS with barometric altimeter.

The radiocarbon ages were determined using a $0.5 \mathrm{MeV}$ accelerator mass spectrometer at the Center for Applied Isotope Studies at the University of Georgia, which was calibrated with the software Calib 5.01 (Stuiver et al., 2005). For ages younger than $11{ }^{14} \mathrm{C}$ kyr BP calibration was in accordance with the Southern Hemisphere (McCormac et al., 2004) calibration curve and for ages older than 11 ${ }^{14} \mathrm{C}$ kyr BP it conformed to the Northern Hemisphere calibration curves (Reimer et al., 2004). Organic soil was collected in high density plastic bags at a depth of $10 \mathrm{~cm}$ below the surface. The $\delta^{13} \mathrm{C}$ values of the soil samples collected in glacial lake deposits are between -23.52 y $-25.1 \%$ o $\delta^{13} \mathrm{C}_{\mathrm{PDB}}$, which are consistent with the C3 land plant signature (Meyers, 1994). This suggests that the organic matter was derived from plants in the surrounding areas of the lake and that a reservoir effect does not exist.

In addition, radiocarbon ages were determined for trapped gastropod shells collected at a depth of about $7 \mathrm{~cm}$ in the external crust of the thrombolites, to prevent superficial contamination. The thombolites had been forming when the lake was closed, so that a reservoir effect produced by glacial meltwater is unlikely. However, the gastropods could potentially have a reservoir effect produced by dissolved, older carbonates from groundwater inflow.

\section{Paleolacustrine levels}

\subsection{Terraces between Lago Sarmiento and La- guna Amarga}

Lago Sarmiento is an elliptical, closed basin with a surface area of $86.2 \mathrm{~km}^{2}$ and a shoreline of $78.3 \mathrm{~km}$, lying at an elevation of $75 \mathrm{~m}$ a.s.l. We recognized four terraces that in some areas eroded the Cerro Toro Formation and in others are covered by regolith. Terraces S1, S2, T3 and T4 range in elevation between 85-90, 105-110, 120-130, and 138-145 m a.s.l., respectively (Fig. 3). Terraces $\mathrm{T} 4$ and $\mathrm{T} 3$ were not observed along the eastern shore of the lake (Fig. 4), occurring mainly on its northern and western slopes (Fig. 5). These terraces were also observed east of moraine $\mathrm{E}$ but not west thereof. Terraces S2 and S1 are present at Lago Sarmiento Chico. A watershed at $86 \mathrm{~m}$ a.s.l between Lago Sarmiento and Lago Sarmiento Chico (Fig. 5b) can also be observed. On the western side of Lago Sarmiento Chico an outlet of the paleolake was developed at the S2 level (Fig. 4).

The $\mathrm{S} 1$ Terrace (85-90 $\mathrm{m}$ a.s.l) is underlain by approximately $8 \mathrm{~m}$ (from the lake level at about $77 \mathrm{~m}$ a.s.l) of carbonate deposits developed along almost the full extent of the coastline. These microbialite deposits are composed of sand, aragonitic gastropod shells and filamentous cyanobacteria enclosed by a clotted structure of calcite. The clotted structure, observed at field, hand sample and microscopic scale, define these bioherms as thrombolites. Gastropods shells collected from the top level (about $83 \mathrm{~m}$ a.s.l) at a depth of $7 \mathrm{~cm}$ within the external crust of the thrombolites, yielded a median probability radiocarbon age of $1,215 \mathrm{Cal}$ yr BP $\left(1,341 \pm 52{ }^{14} \mathrm{C}\right.$ yr BP) and represent an age reflecting the end of growth and precipitation at this level (Solari et al., 2010).

In the sector of Laguna Paso a lacustrine paleopassage between the Lago Sarmiento and Nordenskjöld Basins can be observed at $115 \mathrm{~m}$ a.s.l, the upper limit of which is marked by the continuation of the T4 and T3 Terraces observed on the eastern and western slopes of Laguna Paso (Fig. 5c). It is possible to trace the S2 and S1 Terraces uninterruptedly around Lago Sarmiento, but they do not continue northward into the Laguna Paso passage (Fig. 4). At a $115 \mathrm{~m}$ a.s.l watershed present in the Laguna Paso passage only the T3 and T4 Terraces are observed.

Terraces T4 and T3 represent an old proglacial lake level developed by meltwater from Glacial Advance E. These levels are observed at the 115 $\mathrm{m}$ a.s.l watershed and continue eastward into Lago Nordenskjöld. Terraces S2 and S1 delineate a single paleolake that included both Lago Sarmiento Chico and Lago Sarmiento. This paleolake drained westward into Lago Pehoe and the $86 \mathrm{~m}$ a.s.l watershed between Lago Sarmiento Chico and Lago Sarmiento indicates the elevation where this paleolake was formed and closed by at least 1,215 Cal yr BP. 


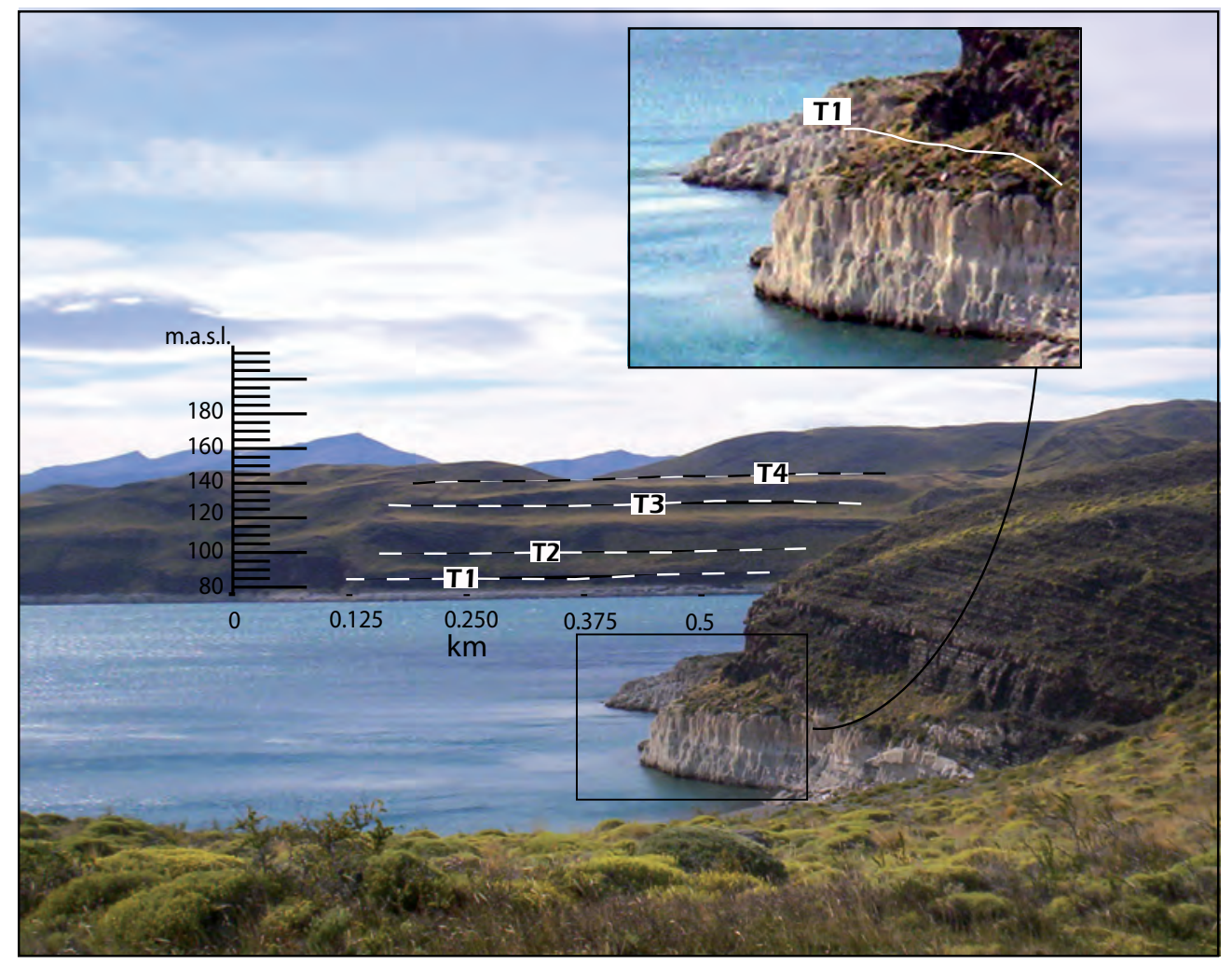

FIG. 3. Terraces along shores of Lago Sarmiento.

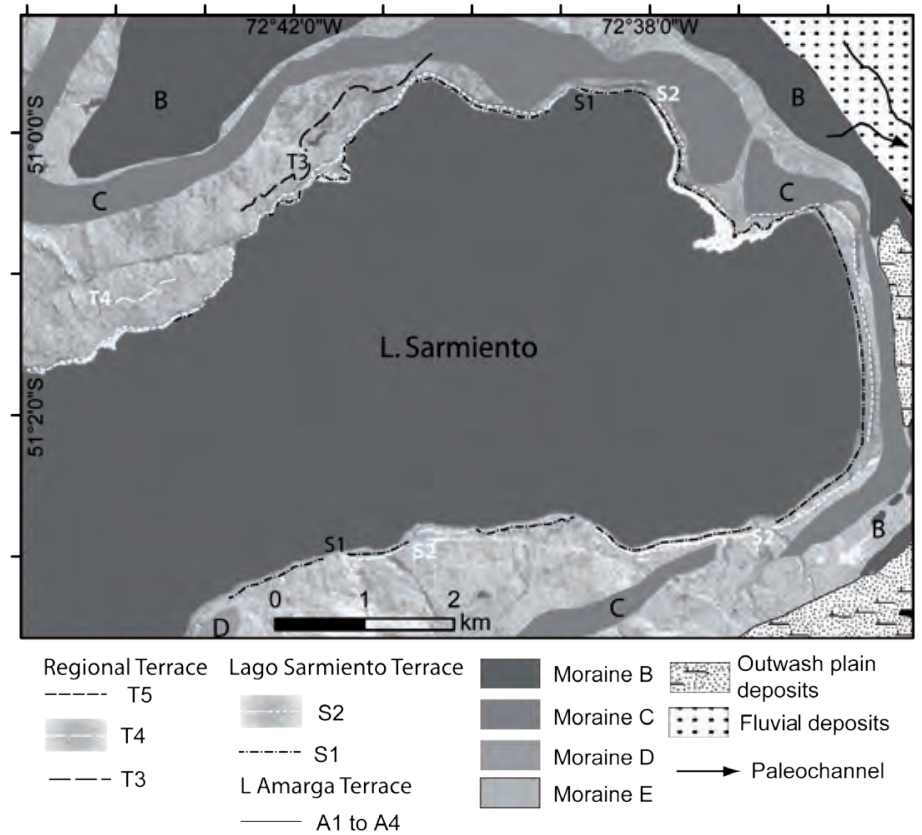

FIG. 4. Aerial photograph of the eastern area of Lago Sarmiento showing the mapped paleo-lacustrine terraces and the legend for figures 5, 6 and 7 . 


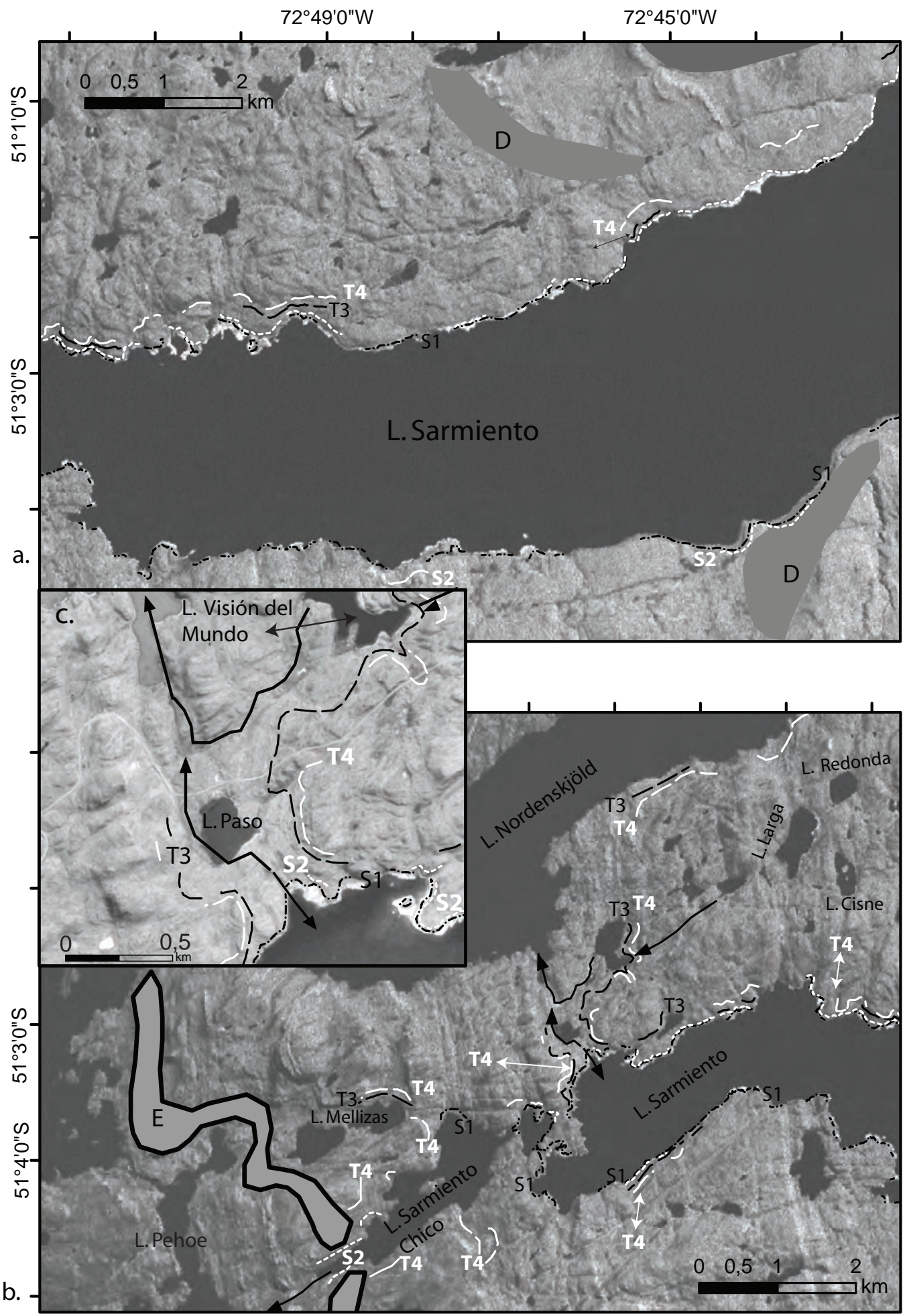

FIG. 5. Aerial photograph showing the mapped paleo-lacustrine terraces: a. Central part of Lago Sarmiento; b. Western part of Lago Sarmiento and southern margin of Lago Nordenskjöld; c. Magnification of the watershed in the Laguna Paso passage. 
Terraces T4 and T3 continue northward from Laguna Paso to the eastern shore of Laguna Visión del Mundo. They also stretch eastward to the southern shore of Lago Nordenskjöld, but can hardly be discerned along its northern shore (Figs. 4 and 5a).

Terraces T3 and T4 continue from Lago Nordenskjöld eastward to the southern paleo-lobes of Moraine Complex D. The T4 Terrace was observed on both flanks of the Paine River valley and eroded the northern paleo-lobe moraine of the D Glacial Re-advance. Terrace T5 (150 to $155 \mathrm{~m}$ a.s.l), was recognised east of Moraine Complex D (Fig. 6). Furthermore, at the margin of Moraine Complex D north of the Paine Waterfall, deformed lacustrine deposits are in contact with diamictic moraine deposits, which indicates that the D Re-advance terminated in a proglacial lake.

Seven terraces (A1, A2, A3, A4, T3, T4 and T5 in Fig. 6) were observed along the slopes of Laguna Amarga. Terraces A1, A2, A3, A4, T3, T4 and T5 occur at mean altitudes of about 82, 90, 98, 108, 125, 138 and $150 \mathrm{~m}$ a.s.l, respectively.

Terraces T3 to T5 are regional levels and Terraces A1 to A4 are local levels that formed when the water level dropped below the watershed between Laguna Amarga and the Paine River at 120 m a.s.l, when the lake became closed. In the Laguna Amarga Peninsula below Terrace T3, a group of thrombolites are present with an internal clotted structure formed by calcite and gastropods. The latter yielded a median probability radiocarbon age of 7,113 Cal yr BP and represent the time when the water level dropped below the T3 elevation ( $<120 \mathrm{~m}$ a.s.l).

\subsection{Terraces around Lago del Toro}

The surface of Lago del Toro is at an elevation of about $25 \mathrm{~m}$ a.s.l., covering an area of $195.1 \mathrm{~km}^{2}$ and occupying a deep asymmetric basin south of the Toro Mountain Range. Well-developed terminal moraines were mapped along the eastern margin of Lago del Toro (Fig. 7). The Peninsula and Ballena Ranges divided the ice sheets into three main lobes, namely the Lago del Toro, Bahía Bote and Lago Porteño lobes. Due to the fact that the regional Terrace T5 related to Glacial Advance D (12,000-15,000 yr BP) was observed in the terminal moraines on the northern slopes of the Ballena Range, it can be deduced that the western moraine ridges of Lago del Toro are correlated with Moraine Complex C exposed at Lago Sarmiento.

In the Lago del Toro lobe, Moraine Complex A reaches $120 \mathrm{~m}$ a.s.l and is composed of two well-defined ridges with boulders on their surface. Moraine Complex B has a maximum elevation of $90 \mathrm{~m}$ a.s.l and shows at least three main ridges. Moraine Complex C attains an elevation of $100 \mathrm{~m}$ a.s.l and is composed of two main ridges. On an island within Lago del Toro a terminal moraine occurs that reaches $65 \mathrm{~m}$ a.s.l and is correlated with Glacial Advance D.

East of Lago del Toro terminal moraines are present on three levels of terraces with a regional extent. The highest of these (T6) lies at an elevation of 240 to $260 \mathrm{~m}$ a.s.l. and is always located east of Moraine Complex A. It is very well preserved at the western limit of Cazador Range (Fig. 8) and in the northern sector of the Rogers Range. Above level T6 are whaleback structures which indicate glacial action predating the formation of the T6 Terrace. These older glacial events are probably related to the terminal moraines mapped at the source of the Don Guillermo River (Fig. 2).

Terrace T5, previously described in the Laguna Amarga sector and linked to Glacial Advance D, is present on both sides of the Tres Pasos River and the Tres Pasos moraine. This terrace is again observed north of Lago Figueroa on the eastern flank of the Jorge Montt Range, where it occurs at an elevation between 150 and $165 \mathrm{~m}$ a.s.l. It is particularly well preserved at the foot of the western slopes of the Rogers Range.

Terrace T4 lies at an elevation between 135 and $145 \mathrm{~m}$ a.s.l. At the foot of the Cazador Range, this terrace extends from near the town of Cerro Castillo to the extreme northern part of the range. Along the northern shore of Lago del Toro it forms small peninsulas extending into the lake. In front of the CONAF Administration Building, T4 is also observed immediately southeast of Glacial Advance $\mathrm{E}$, from where it disappears towards the west.

\section{Sedimentary deposits}

\subsection{Fluvial deposits}

The activity of the Las Chinas, Baguales and Don Guillermo Rivers during part of the Holocene eroded the underlying strata (Cerro Toro, 


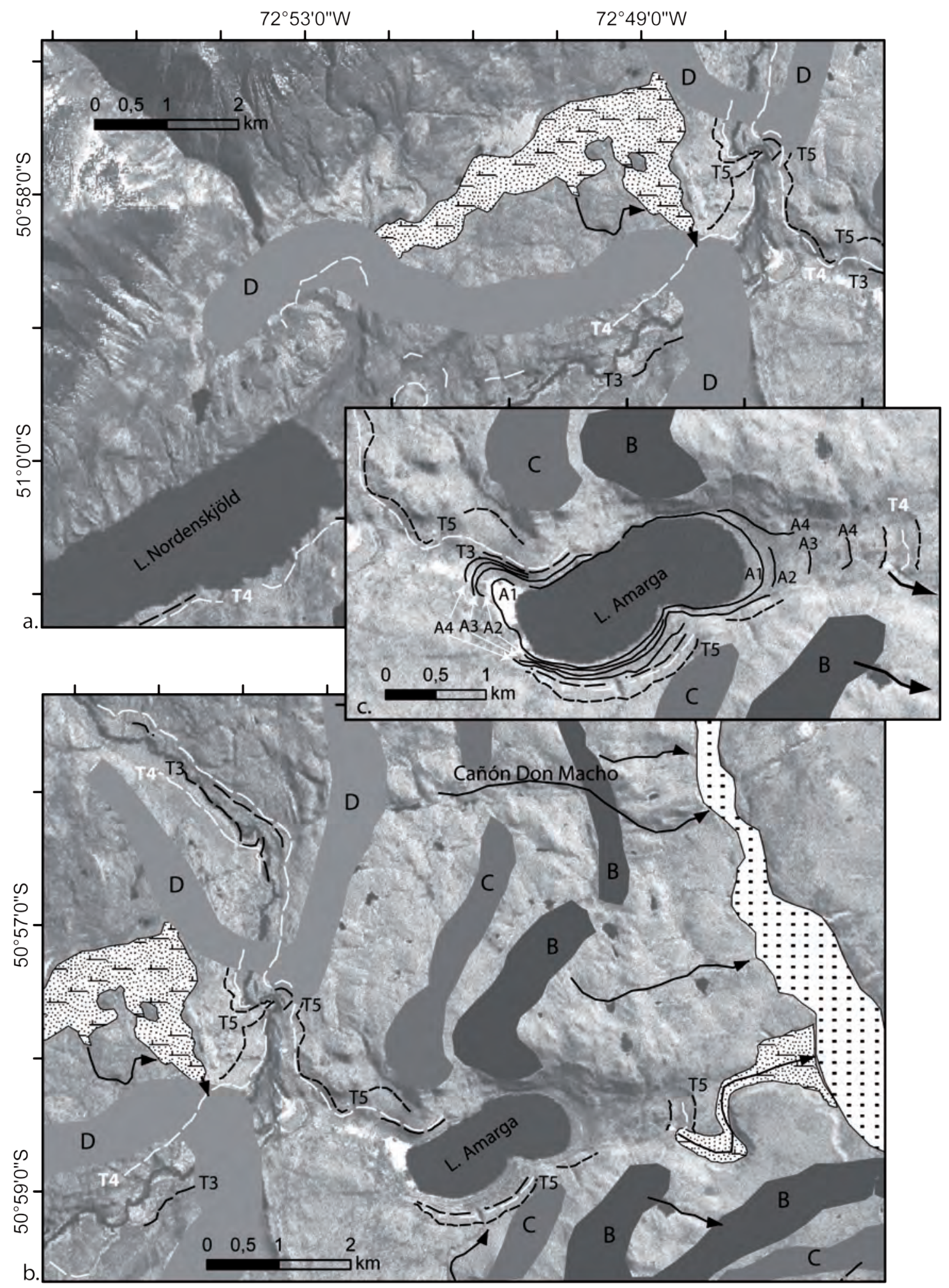

FIG. 6. Aerial photograph showing the mapped paleo-lacustrine terraces: a. Eastern part of Lago Nordenskjöld to Paine River; b. From Paine River to Laguna Amarga; c. Magnification of Laguna Amarga showing the local terraces. 


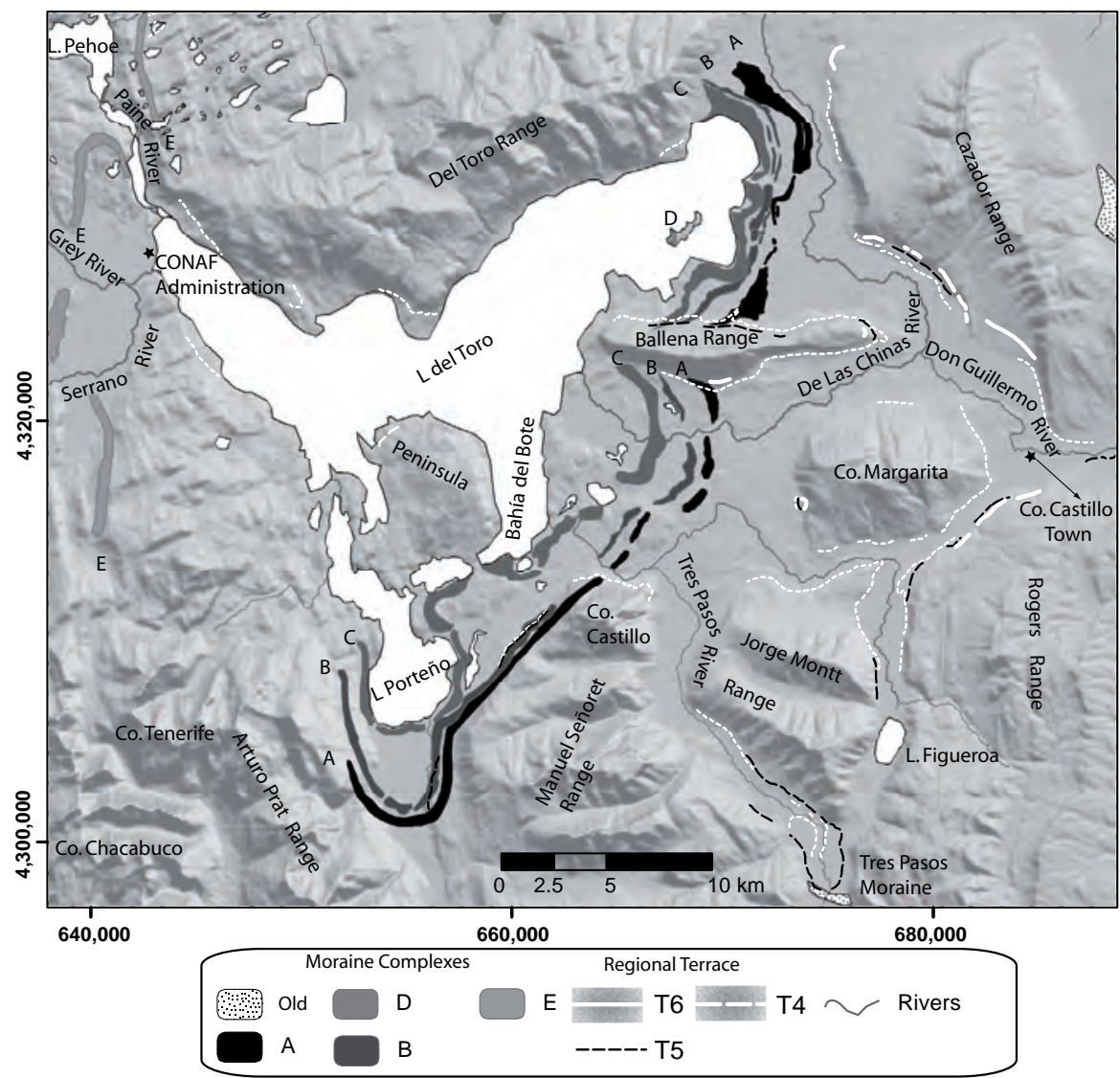

FIG. 7. Glacial moraine complexes, drainage system and regional terraces superimposed on a shaded relief image obtained from the Shuttle Radar Topographic Mapping Mission (SRTM 90 m resolution, UTM 19º / WGS 84) digital elevation model.

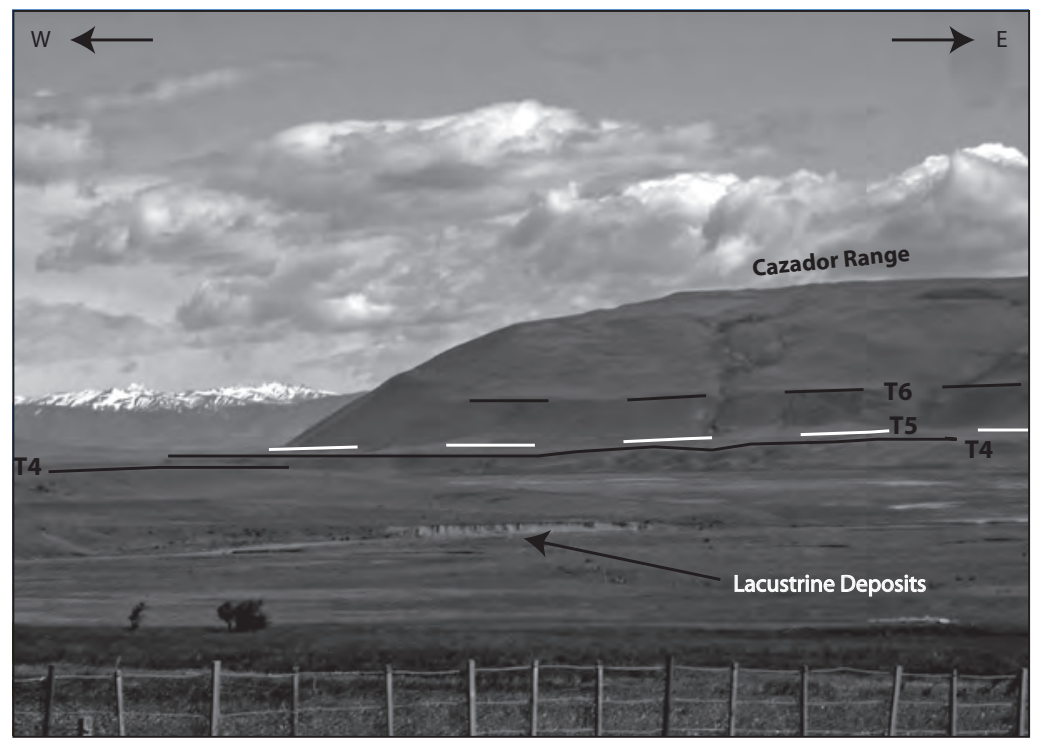

FIG. 8. Terrace levels observed in the Toro Range, as well as peninsulas extending into Lago del Toro. 
Río Baguales and other formations) and in their meandering sectors formed wide alluvial plains with silt and fine to medium sand deposits. However, in their upper reaches these rivers transport gravels and cobbles included in a fine to coarse, arenaceous matrix.

\subsection{Lacustrine deposits}

Lacustrine deposits recognized west of the Cazador Range add new evidence about the existence of an extensive lake to the east of the terminal moraines. These poorly consolidated deposits are composed of a finely stratified succession of sandstones and siltstones with dropstones and occasional load structures. The light to dark grey sandstone beds are fine to coarse, with planar and trough cross-stratification (troughs reaching up to $40 \mathrm{~cm}$ in width), sub-horizontal stratification or massive bedding. They frequently contain siltstone lenses. The siltstone beds are white or light grey to light brown, finely laminated or massive, and contain occasional sandstone lenses.

\subsection{Fluvio-lacustrine deposits}

Between the Baguales and Cazador Ranges fluvio-lacustrine deposits were recognized, especially in drainage channels near the confluence of the Las Chinas and Baguales Rivers (locality 2 in Fig. 9). Here profiles up to $4 \mathrm{~m}$ thick are exposed, which consist of (from bottom to top):

- Clast-supported gravels with an arenaceous matrix. The polymictic clasts (lavas, sandstones, etc.), which vary between 1 and $90 \mathrm{~cm}$ in diameter, are rounded with a median sphericity and poor sorting.

- Silts and finely stratified, grey to brown sands. Gravel lenses within the sand show occasional planar cross-beds. Gravel lenses with $0.5-8 \mathrm{~cm}$, subrounded, polymictic clasts within a sandy matrix also cross-cut the bedding within the sand-silt unit, forming wedge-shaped structures reminiscent of the stone polygons typical of permafrost areas.

- Brown soil profile composed of clays, silts and fine, massive sand. Occasional bone fragments of Lamae guanicoe were also observed, one of which was dated at $878.9 \pm 42{ }^{14} \mathrm{C}$ yr BP (793 Cal yrs BP).

\subsection{Glacio-fluvio-lacustrine deposits at El Canal}

In the El Canal drainage channel, located on the eastern side of Lago del Toro (location 3 in Fig. 9), lacustrine, glacial and fluvial deposits discordantly overlie the Cretaceous marine deposits of the Cerro Toro Formation. A generalized column for these deposits shows that they are composed (from base to the top) of the following units (nomenclature from Eyles et al., 1983):

- Dcm1: A well-consolidated, clast- to matrixsupported basal moraine up to $4.2 \mathrm{~m}$ thick. The clasts are polymictic (including sandstone clasts of the underlying Cerro Toro Formation) and angular with poor sphericity, reaching up to $1 \mathrm{~m}$ in diameter, whereas the matrix is composed of white silt.

- Fl: A lacustrine succession generally more than $10 \mathrm{~m}$ thick, well exposed over the whole length of the channel. It is composed of white to grey silts and laminated sands, frequently varved, with wave ripples. Within the laminated strata are dark brown silts with a high organic matter content (Fig. 10), that have been radiocarbon-dated at $18,100 \pm 100{ }^{14} \mathrm{C}$ yr BP (21,493 Cal yr BP). Along El Canal a shear stress zone showing contorted, laminated or waverippled silt to silty clay units also occurs.

The lacustrine succession displays a variety of subglacial deformation structures, which include and are concentrated along two major thrust faults dipping westward and occurring below the terminal ridges of the C and B Moraine Complexes. Smaller-scale deformation structures include contorted laminated or wave-rippled silt to silty clay, recumbent folds in fine to very fine sandstone beds, and low- to steepangled reverse faults with cm-scale displacement. Such structures are common features in glacial deposits, resulting from the shear stress induced by the glaciers as they advance over previously deposited glacial strata (e.g., Boulton and Hindmarsh, 1987; Alley, 1991).

Within the lacustrine succession two delta deposits are recognised, one overlying the other conformably. The lower delta was dated in its uppermost beds at $20,300 \pm 110{ }^{14} \mathrm{C}$ yr BP $(24,291 \mathrm{Cal}$ yr $\mathrm{Bp}$ ) and shows foresets onlapping towards the west, whereas the upper delta foresets onlap towards the east. The latter is interpreted to have formed by currents migrating from the Cazador Range sector towards Lago del Toro, as a result of the glacial retreat. On the other hand, the upper delta foresets 


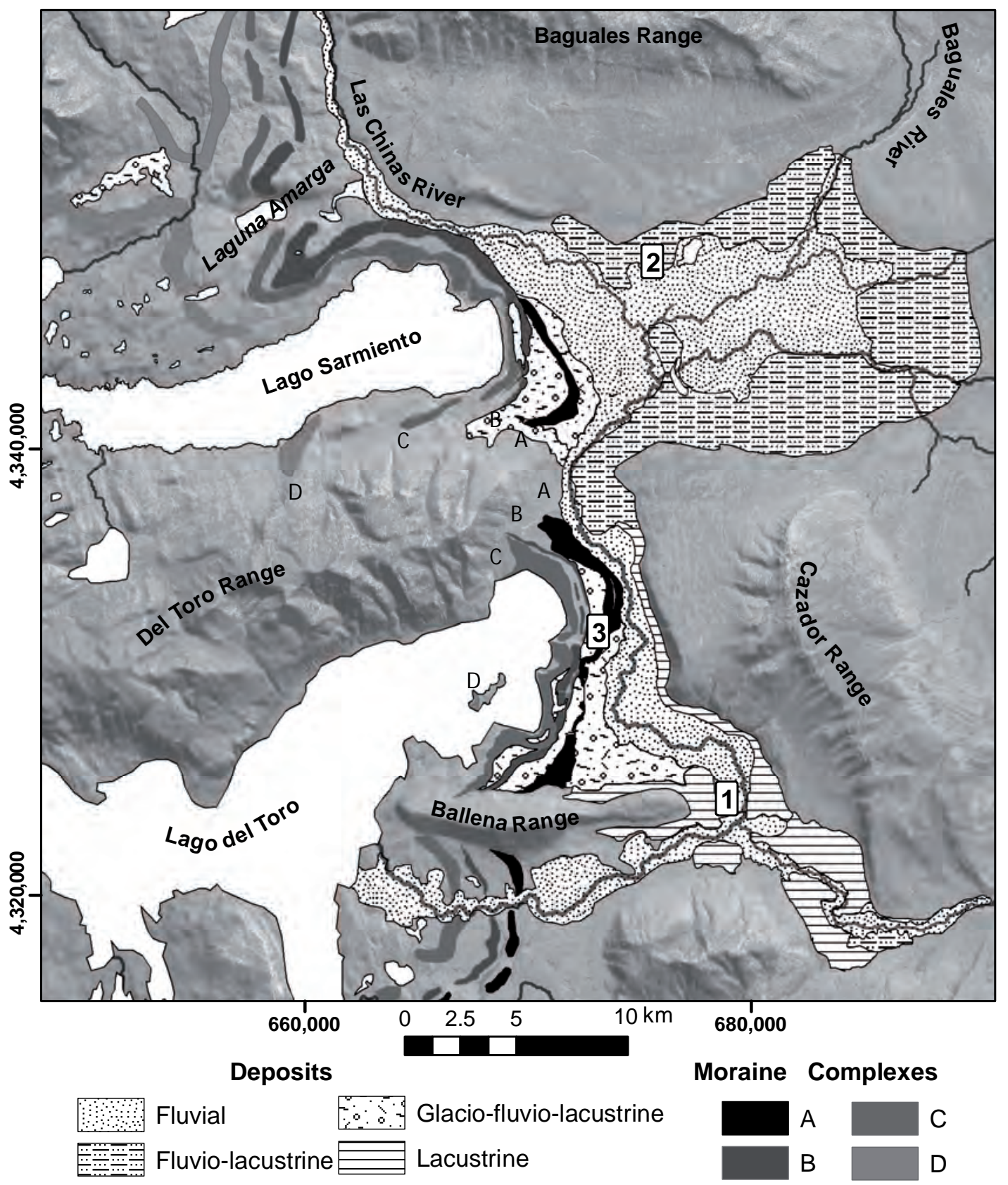

FIG. 9. Sedimentary deposits east of the moraine complexes of Lago del Toro and Lago Sarmiento. The numbers indicate the localities where sedimentary units are described.

are interpreted as a product of current migration towards the east in response to a glacial advance after 24,291 Cal yr BP.

- Dcm2: Basal moraine deposits unconformably overlying the lacustrine succession (Fig. 10) are composed of clast- to matrix-supported gravels. The matrix is composed of white to grey silt, whereas the polymictic clasts are angular to subangular with a medium sphericity and poor sorting. They vary from millimeters to meters in diameter, some show- 
ing facets and striations. The deposits are linked to Glacial Advances A, B and C and dating shows that they are less than but close to 21,493 Cal yr BP. It seems very likely that the glacial advances occurred during the Last Glacial Maximum.

- Sm: Alluvial deposits unconformably overlie the basal moraine and are composed of brown, massive, fine-grained sands with plant roots. They have between $3 \%$ and $6 \%$ polymicitic clasts varying in size between $7 \mathrm{~cm}$ and $3 \mathrm{~mm}$, which are subrounded with a poor sphericity, generally forming subhorizontal flat pebbles. Within these deposits are bone fragments of Lamae guanicoe, one of which was dated at $240 \pm 30{ }^{14} \mathrm{C}$ yr BP, or a calibrated age of 200 Cal yr BP.
- Gmm: Flood deposits unconformably overlie the alluvial deposits. They are composed of gravels with matrix-supported cobbles. These poorly sorted deposits are massive with a white to brown matrix. Clasts vary in concentration between 5 and $40 \%$ and are subrounded and polymictic, with sizes ranging between 0.5 and $45 \mathrm{~cm}$, but clasts derived directly from erosion of the underlying strata are between 25 $\mathrm{cm}$ and $330 \mathrm{~cm}$ in diameter. Tree bark fragments up to $40 \mathrm{~cm}$ long, as well as scarce clasts of travertine up to $10 \mathrm{~cm}$ long were also encountered. A piece of tree bark was dated at $391 \pm 30{ }^{14} \mathrm{C}$ yr BP, or a calibrated age of $200 \mathrm{Cal} \mathrm{yr} \mathrm{BP}$. This unit is interpreted as having been produced during a major flooding of the Las Chinas River.
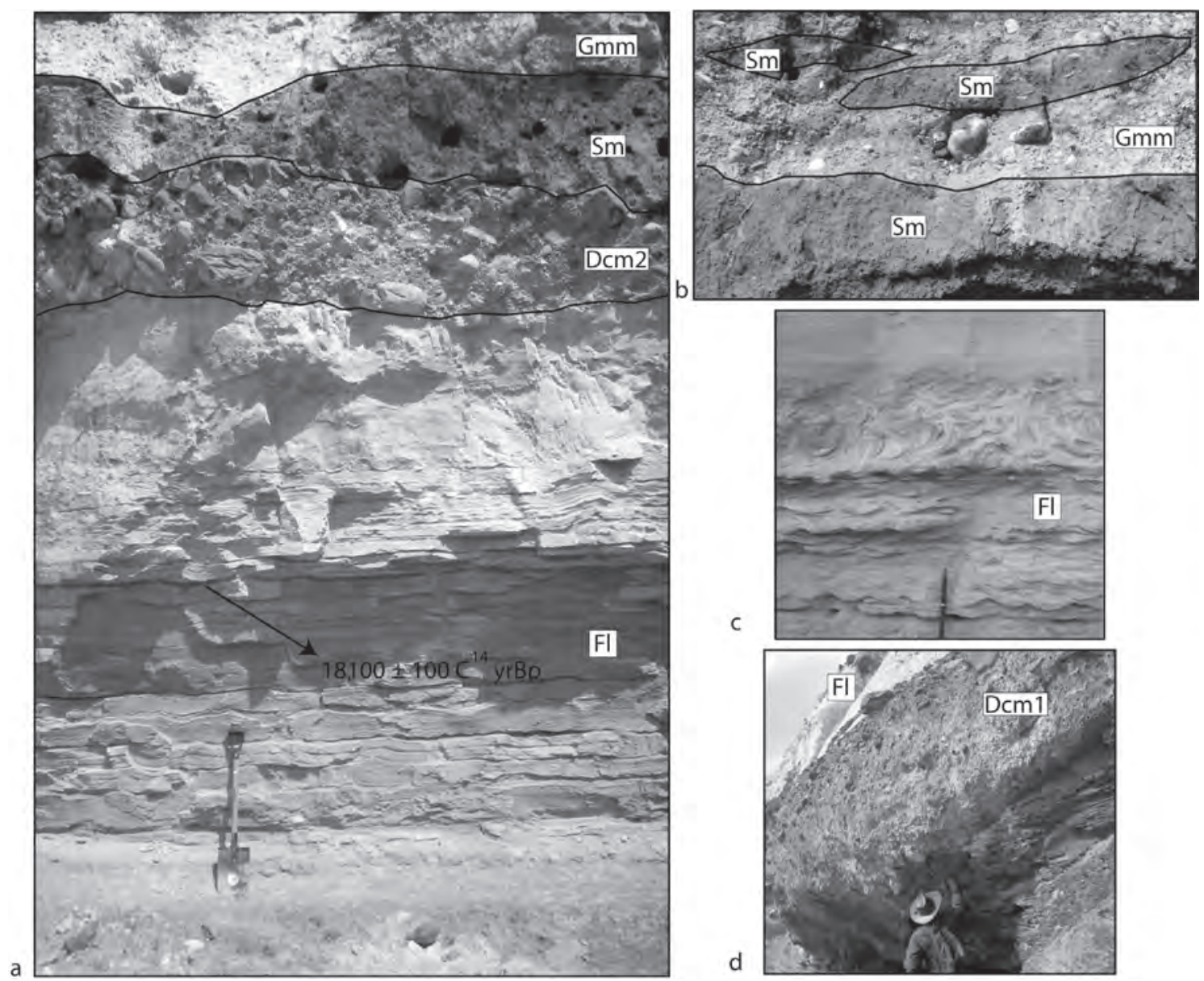

FIG. 10. Deposits along El Canal: a. Stratigraphic columns showing the main units; b. Flood deposits with angular fragments from the underlying alluvial deposits; c. Wave-rippled and contorted beds; d. Consolidated basal moraine overlying the Cerro Toro Formation and underlying the lacustrine succession. From older to younger: Dcm1: Consolidated basal moraine; Fl: Lacustrine succession; Dcm2: Basal moraine; Sm: Alluvial deposits; Gmm: Flood deposits. 


\section{Discussion and Conclusions}

Evidence for older glacial events is provided by the terminal moraine located along the eastern boundary of the TPDB and in the Tres Pasos River area, as well as the consolidated basal moraine deposits that discordantly overlie the Cerro Toro Formation in the El Canal area. These moraine complexes were formed prior to the LGM and further investigation will be necessary to determine whether they developed during the MIS 6 and/or during the Great Patagonian Glaciations (early Pleistocene) as in Lago Buenos Aires (e.g., Ton-That et al., 1999; Singer et al., 2004).

Based on their lateral continuation and location east of the terminal moraines of Glacial Stages E, D, C, B and A, four important, regionally extensive terrace levels are recognized, namely T6, T5, T4 and T3 (Fig. 11). These observations support the existence of a single proglacial water body, which we call the Great Tehuelche Paleolake (GTP). This paleolake formed between the glacial mass and the topographic rise at the eastern margin of the TPDB. The Great Tehuelche Paleolake had an outlet towards the south along the Prat Valley between the Arturo Prat and Manuel Señoret Mountain Ranges.

During the LGM, the GTP received extensive deposits and formed the highest paleolake level described so far in the area. The T6 level varies in elevation between 240-260 $\mathrm{m}$ a.s.l and formed before and during Glacial Advances C, B and A (Fig. 11). In the sector of El Canal, the eastward change in progradation of the upper delta is interpreted as reflecting the beginning of glacial advance after 24,291 Cal yr BP. Moraine Complex B developed at the eastern margin of Lago del Toro after 21,493 Cal yr BP, as evidenced by the intensive deformation that affected the lacustrine succession below the basal till. Glacial Advance C was stable until about 17,500 yr BP, at which moment widespread (a)

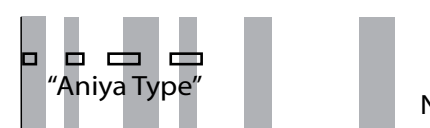

(b)

(c)

b)

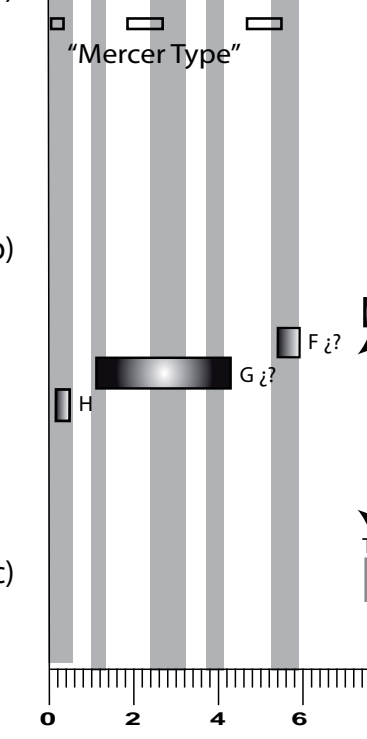

Holocene

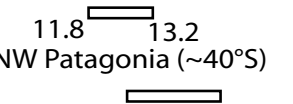

$12.6 \quad 14.8$ SW Patagonia $\left(\sim 51^{\circ} \mathrm{S}\right)$

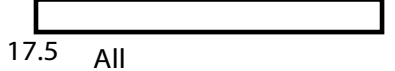

Patagonia

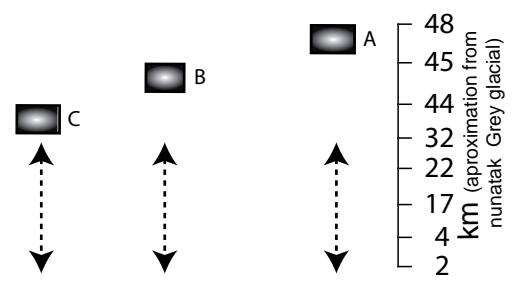

T6

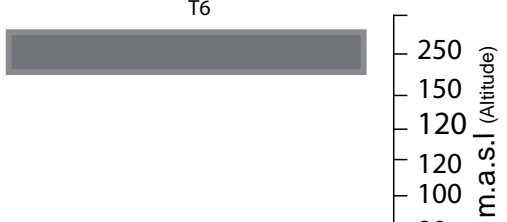

$-90$

$-80$

FIG. 11. Grey bands represent timing of the HRCC (Mayewski et al., 2004) and white rectangles represent cool periods. a. 'Mercer' and 'Aniya' type Neoglacier advance events (see Section 2) in Patagonia (Mercer, 1968, 1970, 1982; Aniya, 1995, 1996); Cold Reversal Period in Lake District of northwestern Chilean Patagonia (Hajdas et al., 2003; Moreno et al., 2001); Cold Reversal Period in Torres del Paine (Moreno et al., 2009) and synchronous Patagonian LGM deglaciation; b. Chronology of the moraine complexes of Torres del Paine; c. Chronology of the terrace levels of the Great Tehuelche Paleolake. 
deglaciation commenced in Patagonia. The T6 Terrace indicates an episode during which the Great Tehuelche Paleolake reached its maximum extent during the LGM, and its level varied as a function of the glacial fluctuation (Fig. 12).

A new phase of the Great Tehuelche Paleolake developed at 12,600-14,800 yr BP during Glacial Re-advance D, at an altitude of 150-165 m a.s.l. The regional Terrace $\mathrm{T} 5$ on the northern flank of the Ballena Range extends west of the moraine ridges on the eastern shore of Lago del Toro and also formed a moraine ridge on an island within this lake, so that the position of the terminal moraines of Glacial Advance D in this sector can be inferred to have been within Lago del Toro.

Terraces T4 and T3 are widespread in the area and are always observed east of Glacial Advance E, at an altitude that varies between 135-145 and
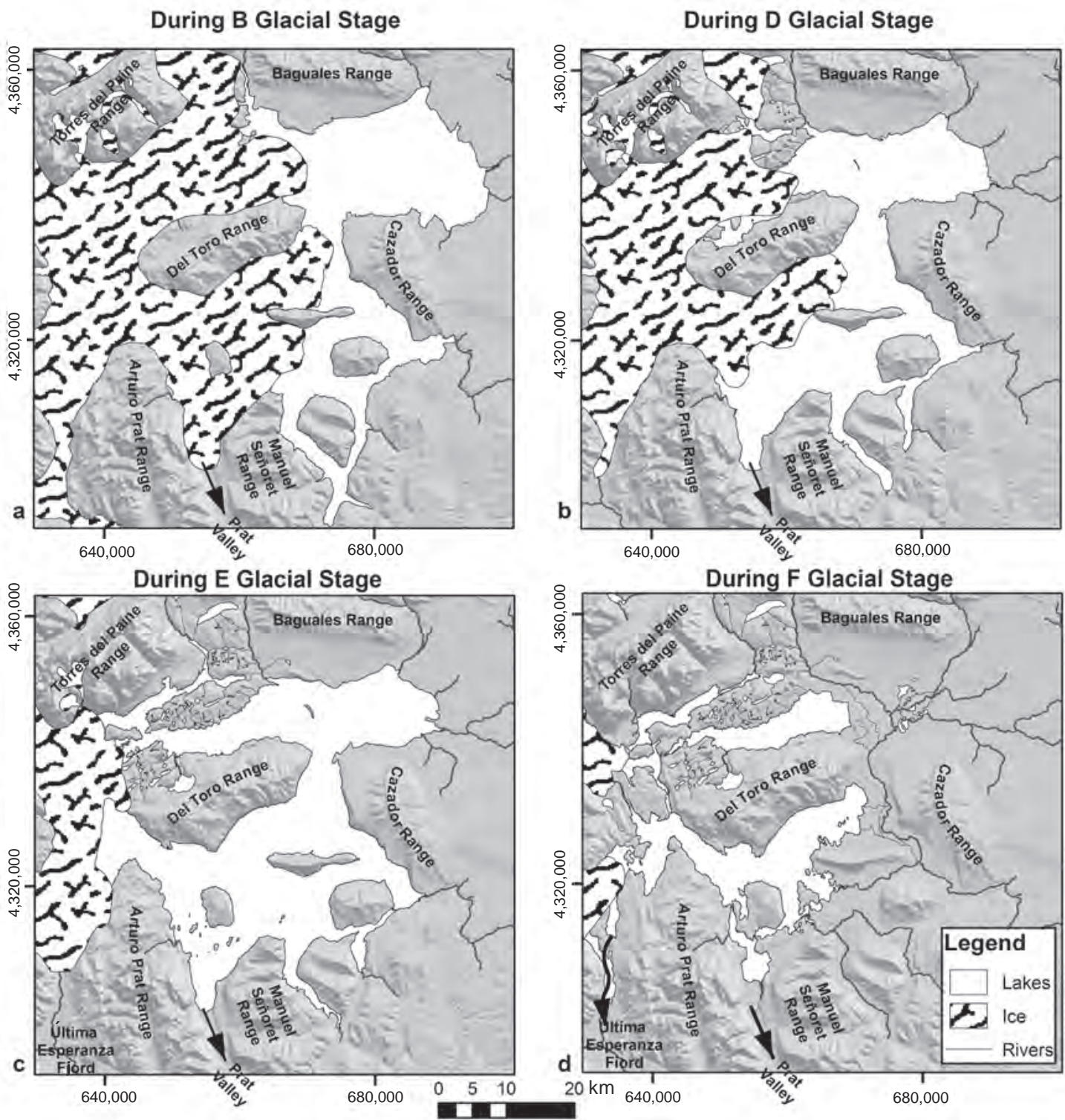

FIG. 12. Reconstruction of the Great Tehuelche Paleolake during the different glacial stages: a. Glacial and lake extension during Glacial Stage B; b. Glacial and lake extension during Glacial Stage D; c. Glacial and lake extension during Glacial Stage E.; d. Small lake organization during Glacial Stage F. 
120-130 m a.s.l., respectively. They represent ancient proglacial lake levels, eroded mainly by meltwater from Glacial Advance $E$ and forming the last stage of the GTP prior to its cessation by drainage (Fig. 12). When the water level of the GTP dropped below the T3 elevation (<120 m a.s.l.), Laguna Amarga became a closed lake with growing thrombolites that trapped gastropods dated at 7,113 Cal yr BP. This moment in time represents the retreat of Glacial Advance $\mathrm{E}$ and the restructuring of the GTP as a group of small lakes similar to the present configuration, as a result of the opening of a new lake outlet that drained towards the Última Esperanza Fjord (Fig. 12). From this time on Laguna Amarga was a closed lake and the salinity of the lake increased because evaporation exceeded precipitation, enough to support the growth of thrombolites. A possible explanation for this salinity increase is that the glacial retreat was caused by reduced precipitation, i.e., more arid conditions prevailed.

We conclude that Glacial Advances $\mathrm{E}$ and $\mathrm{F}$ are younger than the ages previously proposed by Marden and Clapperton (1995). Glacial Advance E culminated before 7,113 Cal yr BP, which approximates the glacial maximum of $8.5 \pm 0.7 \mathrm{kyr}\left({ }^{10} \mathrm{Be}\right)$ dated by Douglas et al. (2006) in the Fachinal Moraine located at Lago General Carrera. However, it will be necessary to gather more regional evidence in Patagonia to establish a definite correlation with the 8,000-9,000 yr BP Northern Hemisphere cool interval. If this proves to be the case, it would support the idea that in this period the climatic changes were synchronous in the Northern and Southern Hemispheres. Glacial Advance $\mathrm{F}$ is younger than 7,113 Cal yr BP and is probably synchronous with the older Neoglacial 'Mercer' type chronology, but further dating is necessary to assign a definite age to this glacial event.

The magnitude and position of the Westerlies is controlled by the subpolar low-pressure belt and the Southeast Pacific Anticyclone, potentially affecting both high-(southern) latitude and tropical Pacific forcing mechanisms (Cerveny, 1998). Supporting the hypothesis of Toggweiler and Russell (2008) derived from the oceanic registers, the delay recorded in the Lake District of south-central Chile with respect to the synchronous cold event in Antarctica and Torres del Paine (Fig. 11), could be explained by a modification of the Westerlies caused by the strengthening of the Tropical Easterlies and the nor- thward expansion of the subpolar low-pressure belt. Strengthening of the Tropical Easterlies is supported by an increase in summer precipitation from 14-11 k cal. yr BP in the Atacama Desert, as interpreted from pollen evidence by Maldonado et al. (2005). Lamy et al. (2004) also interpreted a northward displacement of the Antarctic Circumpolar Current (ACC) during the Cold Reverse Period (closely following upon the YD event), detected at site 1233 in the Los Lagos District.

\section{Acknowledgments}

We gratefully acknowledge financial support by the Comisión Nacional de Investigación Científica y Tecnológica (CONICYT) and the Project 'Geological Connection between the Antarctic Peninsula and Patagonia' (ARTG04) supported by the Programa Bicentenario de Ciencia y Tecnología (PBCT) of CONICYT and the Instituto Antártico Chileno (INACH). Thanks are also due to the Corporación Nacional Forestal (CONAF) for field support, in particular to the rangers. We would also like to thank D. Nieto for field support. Three anonymous referees and the editor provided very useful comments that helped us to improve this paper.

\section{References}

Alley, R.B. 1991. Deforming-bed origin for southern Laurentide till sheets? Journal of Glaciology 37: 67-76.

Andersen, K.K.; Svensson, A.; Johnsen, S.J.; Rasmussen, S.O.; Bigler, M.; Röthlisberger, R.; Ruth, U.; Siggaard-Andersen, M.L.; Steffensen, J.P.; DahlJensen, D.; Vinther, B.M.; Clausen, H.B. 2006. The Greenland Ice Core Chronology 2005, 15-42 ka, Part 1: Constructing the time scale. Quaternary Science Reviews 25: 3246-3257.

Aniya, M. 1995. Holocene glacial chronology in Patagonia: Tyndall and Upsala Glaciers. Arctic and Alpine Research 27: 311-322.

Aniya, M. 1996. Holocene variations of Ameghino Glacier, southern Patagonia. Holocene 6: 247-252.

Armesto, J.J.; Casassa, I.; Dollenz, O. 1992. Age structure and dynamics of Patagonian beech forest in Torres del Paine National Park, Chile. Vegetaio 98: 13-22.

Bender, M.; Sowers, T.; Dickson, M.L.; Orchardo, J.; Grootes, J.; Mayewski, P.A.; Meese, DA. 1994. Climate correlations between Greenland and Antarctica during the past 100,000 years. Nature 372: 663-666.

Blunier, T.; Chappellaz, J.; Schwander, J.; Dällenbach, A.; Stauffer, B.; Stockerk, T.F.; Raynaud, D.; Jouzel, J.; 
Clausen, H.B.; Hammer, C.V.; Johnsen, S.J. 1998. Asynchrony of Antarctic and Greenland climate during the last glacial period. Nature 394: 739-743.

Bond, G.; Broecker, W.; Johnsen, S.; McManus, J.; Layberie, L.; Jouzel, J.; Bonani, G. 1993. Correlations between climate records from North Atlantic sediments and Greenland ice. Nature 365: 143-147.

Bond, G.; Lotti, R. 1995. Iceberg discharges into the North Atlantic on millennial time scales during the last glaciation. Science 267: 1005-1010.

Boulton, G.S.; Hindmarsh, R.C.A. 1987. Sediment deformation beneath glaciers: rheology and geological consequences. Journal of Geophysical Research 92 B9: 9059-9082.

Caldenius, C.C. 1932. Las glaciaciones cuaternarias en la Patagonia y Tierra del Fuego. Geografiska Annaler 14: $1-164$

Carrasco, J.F.; Casassa, G.; Rivera, A. 1998. Climatología actual del Campo de Hielo Sur y posibles cambios por incremento del efecto invernadero. Anales del Instituto de la Patagonia, Serie Ciencias Naturales 26: 119-128.

Carrasco, J.F.; Casassa, G.; Rivera, A. 2002. Meteorological and climatological aspect of the Southern Patagonian Icefield. In The Patagonian Icefield, a Unique Natural Laboratory for Enviromental and Climate Changes Studies (Cassasa, G.F.; Sepúlveda, F.; Sinclair, R.; editors). Kluwer Academic/Plenum Publishers: 29-41. New York.

Cerveny, R.S. 1998. Present climate of South America. In Climates of the Southern Continents: Present, Past and Future (Hobbs, J.E.; Lindesay, J.A.; Bridgman, H.A.; editors). Wiley: 107-134. New York.

Clapperton, C. 1993. Quaternary Geology and Geomorphology of South America. Elsevier: 779 p. Amsterdam.

Clapperton, C.; Seltzer, G. 2001. Glaciation during marine isotope Stage 2 in the American Cordillera. In Interhemispheric Climate Linkages (Markgraf, V.; editor). Academic Press. San Diego.

Clapperton, C.M.; Hall, M.; Mothers, P.; Hole, M.J.; Still, J.W.; Helmens, K.F.; Kuhry, P.; Gemmell, A.M.D. 1997. A Younger Dryas ice cap in the equatorial Andes. Quaternary Research 47: 13-28.

Coronato, A.; Martínez, O.; Rabassa, J. 2004. Pleistocene glaciations in Argentine Patagonia, South America. In Quaternary Glaciations: Extent and Chronology. Part III: South America, Asia, Africa, Australia and Antarctica (Ehlers, J.; Gibbard, P.; editors). Elsevier: 49-67. Amsterdam.

Dansgaard, W.; Johnsen, S.J.; Clausen, H.B.; Dahl-Jensen, D.; Gundestrup, N.S.; Hammer, C.U.; Hvidberg, C.S.;
Steffensen, J.P.; Sveindjörnsdottir, A.E.; Jouzel, J.; Bond, G. 1993. Evidence for general instabilty of past climate from $250 \mathrm{kyr}$ ice-core record. Nature 364: 218-220.

Davis, B.A.S.; Brewer, S. 2009. Orbital forcing and role of the latitudinal insolation/temperature gradient. Climate Dynamics 32: 143-165.

Denton, G.H.; Karlen, W. 1973. Holocene climatic variations-their pattern and possible cause. Quaternary Research 3: 155-205.

Denton, G.H.; Hendy, C.H. 1994. Younger Dryas age advance of Franz Josef glacier in the southern Alps of New Zealand. Science 264: 1434-1437.

Denton, G.H.; Lowell, T.V.; Heusser, C.J.; Moreno, P.I.; Andersen, B.G.; Heusser, L.E.; Schlüchter, C.; Marchant, D.R. 1999. Interhemispheric linkage of paleoclimate during the last glaciation. Geografiska Annaler 81: 107-153

Douglass, D.C.; Singer, B.S.; Kaplan, M.R.; Mickelson, D.M.; Caffee, M.W. 2006. Cosmogenic nuclide surface exposure dating of boulders on last-glacial and late-glacial moraines, Lago Buenos Aires, Argentina: interpretive strategies and paleoclimate implications. Quaternary Geochronology 1: 43-58.

EPICA Community Members. 2004. Eight glacial cycles from an Antarctic ice core. Nature 429: 623-628.

Eyles, N.; Eyles, C.H.; Miall, A.D. 1983. Lithofacies types and vertical profile models, an alternative approach to the description and environmental interpretation of glacial diamict and diamictite sequences. Sedimentology 30: 393-410.

Fogwill, C.J.; Kubik, P.W. 2005. A glacial stage spanning the Antarctic Cold Reversal in Torres del Paine (51 ${ }^{\circ} \mathrm{S}$ ), Chile, based on preliminary cosmogenic exposure ages. Geografiska Annaler 87A: 403-408.

Glasser, N.F.; Jansson, K. 2008. The glacial map of southern South America. Journal of Maps v2008: 175-196. doi: 10.4113/jom.2008.1020.

Glasser, N.F.; Harrison, S.; Winchester, V.; Aniya, M. 2004. Late Pleistocene and Holocene palaeoclimate and glacier fluctuations in Patagonia. Global and Planetary Change 43: 79-101

Glasser, N.F.; Harrison, S.; Jansson, K.; Kleman, J. 2008. The glacial geomorphology and Pleistocene history of southern South America between $38^{\circ} \mathrm{S}$ and $56^{\circ} \mathrm{S}$. Quaternary Science Reviews 27: 365-390.

Hajdas, I.; Bonani, G.; Moreno, P.I.; Ariztegui, D. 2003. Precise radiocarbon dating of Late Glacial cooling in mid-latitude South America: Quaternary Research 59: 70-78. 
Harrison, S. 2004. The Pleistocene glaciations of Chile. In Pleistocene Glaciations: Extent and Chronology (Ehlers, J.; Gibbard, P.; editors). Elsevier: 89-103. Amsterdam.

Heusser, C.J. 1990. Chilotan piedmont glacier in the southern Andes during the Last Glacial Maximum. Revista Geológica de Chile 17: 3-18.

Heusser, C.J. 2003. Ice Age in the Southern Andes: A Chronicle of Palaeoecological Events. Elsevier. Amsterdam.

Heusser, C.J.; Denton, G.H.; Hauser, A.; Andersen, B.G.; Lowell, T.V. 1995. Quaternary pollen records from the Archipiélago de Chiloé in the context of glaciation and climate. Revista Geológica de Chile 22 (1): 25-46.

Ibarzabal y Donángelo, T.; Hoffmann, J.A.J.; Naruse, R. 1996. Recent climatic change in southern Patagonia. Bulletin of Glacier Research 14: 29-36.

Imbrie, J.; Hays, J.D.; Martinson, D.G.; McIntyre, A.; Mix, A.C.; Morley, J.J.; Pisias, N.G.; Prell, W.L.; Shackleton, N.J. 1984. The orbital theory of Pleistocene climate: Support from a revised chronology, of the marine $\delta^{18} \mathrm{O}$ record. In Milankovitch and Climate, Part 1 (Berger, A.; editor), Reidel, Hingham: 269-305. Massachusetts.

Imbrie, J.; Boyle, E.A.; Clemens, S.C.; Duffy, A.; Howard, W.R.; Kukla, G.; Kutzbach, J.; Martinson, D.G.; McIntyre, A.; Mix, A.C.; Molfino, B.; Morley, J.J.; Peterson, L.C.; Pisias, N.G.; Prell, W.L.; Raymo, M.E.; Shackleton, N.J.; Toggweiler, J.R. 1992. On the structure and origin of major glaciation cycles: 1. Linear responses to Milankovitch forcing. Paleooceanography 7: 701-738.

Ivy-Ochs, S.; Schlüchter, C.; Kubik, P.W.; Denton, G.H. 1999. Moraine exposure dates imply synchronous Younger Dryas advances in the European Alps and in the Southern Alps of New Zealand. Geografiska Annaler 81: 313-323.

Jouzel, J.; Masson, V.; Cattani, O.; Falourd, S.; Stievenard, M.; Stenni, B.; Longinelli, A.; Johnsen, S.J.; Steffensen, J.P.; Petit, J.R.; Schwander, J.; Souchez, R.; Barkov, N.I. 2001. A new 27 ky high resolution East Antarctic climate record. Geophysical Research Letters 28: 3199-3202.

Kaplan, M.R.; Ackert, R.P.; Singer, B.S.; Douglass, D.C.; Kurz, M.D. 2004. Cosmogenic nuclide chronology of millennial-scale glacial advances during O-isotope Stage 2 in Patagonia. Geological Society of America Bulletin 116: 308-321.

Kaplan, M.R.; Douglass, D.C.; Singer, B.S.; Ackert, R.P.; Caffee, M.W. 2005. Cosmogenic nuclide chronology of pre-last glaciation maximum moraines at Lago
Buenos Aires, $46^{\circ} \mathrm{S}$, Argentina. Quaternary Research 63: 301-315.

Kaplan, M.R.; Moreno, P.I.; Rojas, M. 2008a. Glacial dynamics in southernmost South America during Marine Isotope Stage 5e to the Younger Dryas chron: A brief review with a focus on cosmogenic nuclide measurements. Journal of Quaternary Science 23: 649-658.

Kaplan, M.R.; Fogwill, C.J.; Sugden, D.E.; Hulton, N.R.J.; Kubik, P.W.; Freeman, S.P.H.T. 2008b. Southern Patagonian and Southern Ocean climate during the last glacial period. Quaternary Science Reviews 27: 284-294.

Lagabrielle, Y.; Scalabrino, B.; Suárez, M.; Ritz, J.-F. 2010. Mio-Pliocene glaciations of Central Patagonia: New evidence and tectonic implications. Andean Geology 37: 276-299.

Lamy, F.; Kaiser, J.; Ninnemann, U.; Hebbeln, D.; Arz, H.W.; Stoner, J. 2004. Antarctic timing of surface water changes off Chile and Patagonian ice sheet response. Science 304: 1959-1962.

Lowell, T.V.; Heusser, C.J.; Andersen, B.G.; Moreno, P.I.; Hauser, A.; Heusser, L.E.; Schlüchter, C.; Marchant, D.R.; Denton, G.H. 1995. Interhemispheric correlation of Late Pleistocene glacial events. Science 269: 1541-1549.

Macayeal, D.R. 1993. Binge/purge oscillations of the Laurentide icesheet as a cause of the North Atlantic's Heinrich events. Paleoceanography 8: 775-784.

Maldonado, A.; Betancourt, J.; Latorre, C.; Villagrán, C. 2005. Pollen analyses from a 50000-yr rodent midden series in the southern Atacama Desert (2530'S). Journal of Quaternary Science 20: 493-507.

Marden, C.J. 1993. Late Quaternary glacial history of the South Patagonian Icefield at Torres del Paine, Chile. Ph.D. Thesis (Unpublished), University of Aberdeen: 298 p.

Marden, C.J.; Clapperton, C.M. 1995. Fluctuations of the South Patagonian Icefield during the last glaciation and the Holocene. Journal of Quaternary Science 10: 197-210.

Mayewski, P.A.; Rohling, E.J.; Stager, J.C.; Karlén, W.; Maasch, K.; Meeker, L.D.; Meyerson, E.; Gasse, F.; Van Kreveld, S.; Holmgren, K.; Lee-Thorp, J.; Rosqvist, G.; Rack, F.; Staubwasser, M.; Schneider, R.R.; Steig, E.J. 2004. Holocene climate variability. Quaternary Research 62: 43-255.

McCormac, F.G.; Hogg, A.G.; Blackwell, P.G.; Buck, C.E.; Higham, T.F.G.; Reimer, P.J. 2004. SHCAL04 Southern Hemisphere Calibration, 0-11.0 Cal kyr BP. Radiocarbon 46: 1087-1092. 
McCulloch, R.D.; Bentley, M.J.; Purves, R.S.; Sugden, D.E.; Clapperton, C.; Hulton, N.R.J. 2000. Climatic inferences from glacial and palaeoecological evidence at the last glacial termination, southern South America. Journal of Quaternary Science 15: 409-418.

McCulloch, R.D.; Fogwill, C.J.; Sugden, D.E. 2005. Late Glacial maxima, the Antarctic Cold Reversal and the Younger Dryas in the Strait of Magellan and Bahía Inútil; a revised chronology. Geografiska Annaler 87: 289-312.

Meglioli, A. 1992. Glacial geology and chronology of southernmost Patagonia and Tierra del Fuego, Argentina and Chile. Ph.D. Thesis (Unpublished), Leigh University: 298 p. Bethlehem, PA.

Mercer, J.H. 1968. Variations of some Patagonian glaciers since the Late-Glacial. American Journal of Science 266: 91-109.

Mercer, J.H. 1970. Variations of some Patagonian glaciers since the Late-Glacial. II. American Journal of Science 269: 1-25.

Mercer, J.H. 1976. Glacial history of southernmost South America. Quaternary Research 6: 125-166.

Mercer, J.H. 1982. Holocene glacier variations in southern Patagonia. Striae 18: 35-40.

Meyers, P.A. 1994. Preservation of elemental and isotopic source identification of sedimentary organic matter. Chemical Geology 144: 289-302.

Milankovitch, M. 1930. Mathematische Klimalehre und Astronomische Theorie der Klimaschwankungen. Handbuch der Klimatologie. Band 1, Teil A. Gebruder Borntraeger, Berlin: 176 p.

Mix, A.C.; Bard, E.; Schneider, R. 2001. Environmental processes of the ice age: land, oceans, glaciers (EPILOG). Quaternary Science Reviews 20: 627-657.

Moreno, P.I.; Jacobson, G.L.; Lowell, T.V.; Denton, G.H. 2001. Interhemispheric climate links revealed by a Late-Glacial cooling episode in southern Chile. Nature 409: 804-808.

Moreno, P.I.; Kaplan, M.R.; François, J.P.; Villa-Martínez, R.; Moy, C.M.; Stern, C.R.; Kubik, P.W. 2009. Renewed glacial activity during the Antarctic Cold Reversal and persistence of cold conditions until $11.5 \mathrm{ka}$ in southwestern Patagonia. Geology 37: 375-378.

North Greenland Ice Core Project Members. 2004. Highresolution record of Northern Hemisphere climate extending into the last interglacial period. Nature 431: 147-151.

NGRIP, North Greenland Ice Core Project Dating Group, 2006. Greenland Ice Core Chronology 2005 (GICC05),
IGBP PAGES. World Data Center for Paleoclimatology Data, Contribution Series \# 2006-118, NOAA/NCDC Paleoclimatology Program, Boulder, USA.

Porter, S.C.; Clapperton, C.M.; Sudgen, D.E. 1992. Chronology and dynamics of deglaciation along and near the Strait of Magellan, southernmost South America. Sveriges Geologiska Undersökning 81: 233-239.

Rabassa, J.; Clapperton, C.M. 1990. Quaternary glaciations in the southern Andes. Quaternary Science Reviews 9: 153-174.

Rabassa, J.; Coronato, A.M.; Salemme, M. 2005. Chronology of the Late Cenozoic Patagonian glaciations and their correlation with biostratigraphic units of the Pampean region (Argentina). Journal of South American Earth Sciences 20: 81-103.

Rasmussen, S.O.; Andersen, K.K.; Svensson, A.M.; Steffensen, J.P.; Vinther, B.M.; Clausen, H.B.; SiggaardAndersen, M.L.; Johnsen, S.J.; Larsen, L.B.; Bigler, M., R. Röthlisberger, R.; Fischer, H.; Goto-Azuma, K.; Hansson, M.E.; Ruth, U. 2006. Anew Greenland ice core chronology for the Last Glacial Termination. Journal of Geophysical Research. doi: 10.1029/2005JD006079.

Reimer, P.J.; Baillie, M.G. L.; Bard, E.; Bayliss, A.; Beck, J.W.; Bertrand, C.J.H.; Blackwell, P.G.; Buck, C.E.; Burr, G.S.; Cutler, K.B.; Damon, P.E.; Edwards, R.L.; Fairbanks, R.G.; Friedrich, M.; Guilderson, T.P.; Hogg, A.G.; Hughen, K.A.; Kromer, B.; McCormac, F.G.; Manning, S.W.; Ramsey, C.B.; Reimer, R.W.; Remmele, S.; Southon, J. R.; Stuiver, M.; Talamo, S.; Taylor, F.W.; van der Plicht, J.; Weyhenmeyer, C.E. 2004. IntCal04 terrestrial radiocarbon age calibration, 26-0 ka BP. Radiocarbon 46: 1029-1058.

Schwander, J.; Jouzel, J.; Hammer, C.U.; Petit, J.R.; Udisti, R.; Wolff E. 2001. A tentative chronology for the EPICA Dome Concordia ice core. Geophysical Research Letters 28: 4243-4246.

Singer, B.S.; Ackert, R.P.; Guillou, H. 2004. ${ }^{40} \mathrm{Ar} /{ }^{39} \mathrm{Ar}$ and K-Ar chronology of Pleistocene glaciations in Patagonia. Geological Society of America Bulletin 116: 434-450.

Solari, M.A.; Hervé, F.; Le Roux, J.P.; Airo, A.; Sial, A.N. 2010. Paleoclimatic significance of lacustrine microbialites: A stable isotope case study of two lakes at Torres del Paine, southern Chile. Palaeogeography, Palaeoclimatology, Palaeoecology 297: 70-82.

Sowers, T.; Bender, M. 1995. Climate records covering the last deglaciation. Science 269: 210-214.

Steig, E.J.; Brook, E.J.; White, J.W.C.; Sucher, C.M.; Bender, M.L.; Lehman, S.J.; Morse, D.L.; Waddington, E.D.; 
Clow, G.D. 1998. Synchronous climate changes in Antarctica and the North Atlantic. Science 282: 92-95.

Stenni, B.; Masson-Delmotte, V.; Johnsen, S.; Jouzel, J.; Longinelli, A.; Monnin, E.; Rothlisberger, R.; Selmo, E. 2001. An Oceanic Cold Reversal during the last deglaciation. Science 293: 2074-2077.

Stenni, B.; Jouzel, J.; Masson-Delmotte, V.; Rothlisberger, R.; Castellano, E.; Cattani, O.; Falourd, S.; Johnsen, S.J.; Longinelli, A.; Sachs, J.P.; Selmo, E.; Souchez, R.; Steffensen, J.P.; Udisti, R. 2003. A late-glacial highresolution site and source temperature record derived from the EPICA Dome C isotope records (East Antarctica). Earth and Planetary Science Letters 217: 183-195.

Stenni, B.; Sachs, J.P.; Selmo, E.; Souchez, R.; Steffensen, J.P.; Udisti, R.; Jouzel, J.; Masson-Delmotte, V.; Rothlisberger, R.; Castellano, E.; Cattani, O.; Falourd, S.; Johnsen, S.J.; Longinelli, A. 2006. EPICA Dome C Stable Isotope Data to 44.8 KYrBP. IGBP PAGES. World Data Center for Paleoclimatology Data Contribution Series \# 2006-112. NOAA/NCDC. Paleoclimatology Program, Boulder, USA.

Stern, C.R. 1990. Tephrochronology of southernmost Patagonia. National Geographic Research 30: 304-314.

Stuiver, M.; Reimer, P.J.; Reimer, R.W. 2005. CALIB 5.0. [WWW program and documentation].

Sugden, D.E.; Bentley, M.J.; Fogwill, C.J.; Hulton, N.R.J.; McCulloch, D.; Purves, R.S. 2005: Late-glacial glacier events in southernmost South America: a blend of 'northern' and southern' hemispheric climatic signals?, Geografiska Annaler 87: 273-288.
Svensson, A.; Andersen, K.K.; Bigler, M.; Clausen, H.B.; Dahl-Jensen, D.; Davies, S.M.; Johnsen, S.J.; Muscheler, R.; Rasmussen, S.O.; Röthlisberger, R.; Steffensen, J.P.; Vinther, B.M. 2006. The Greenland Ice Core Chronology 2005, 15-42 ka, Part 2: Comparison to other records, Quaternary Science Reviews 25: 3258-3267.

Toggweiler, J.R.; Russell, J. 2008. Ocean circulation in a warming climate. Nature 451: 286-2788.

Ton-That, T.; Singer, B.; Mörner, N.; Rabassa, J. 1999. Datación de lavas basálticas por ${ }^{40} \mathrm{Ar} /{ }^{39} \mathrm{Ar}$ y geología glacial de la región del Lago Buenos Aires. Revista de la Asociación Geológica Argentina 54: 333-352.

United States Geological Survey. 2000. Shuttle Radar Topography Mission, 3 Arc Second scene SRTM fB03_p230r096, Filled-Finished B. Global Land Cover Facility, University of Maryland, College Park, Maryland. Source for this data set was the Global Land Cover Facility. http://www.landcover.org.

Vinther, B.M.; Clausen, H.B.; Johnsen, S.J.; Rasmussen, S.O.; Andersen, K.K.; Buchardt, S.L.; Dahl-Jensen, D.; Seierstad, I.K.; Siggaard-Andersen, M.L.; Steffensen, J.P.; Svensson, A.M.; Olsen, J.; Heinemeier, J. 2006. A synchronized dating of three Greenland ice cores throughout the Holocene. Journal of Geophysical Research 111: D13102. doi: 10,1029/2005JD006921

Wenzens, G. 2005. Glacier advances east of the Southern Andes between the Last Glacial Maximum and 5,000 BP compared with lake terraces of the endorrheic Lago Cardiel (495, Patagonia, Argentina). Zeitschrift für Geomorphologie 49: 433-454.

Manuscript received: March 23, 2010; revised/accepted: May 27, 2011; available online: June 3, 2011. 